\title{
Children's television and public service in contemporary Britain
}

Book or Report Section

Accepted Version

Bignell, J. (2017) Children's television and public service in contemporary Britain. In: Dinter, S. and Schneider, R. (eds.) Transdisciplinary Perspectives on Childhood in Contemporary Britain. Studies in Childhood, 1700 to the Present. Routledge, London, UK, pp. 87-102. ISBN 9781138232105 Available at https://centaur.reading.ac.uk/74682/

It is advisable to refer to the publisher's version if you intend to cite from the work. See Guidance on citing.

Publisher: Routledge

All outputs in CentAUR are protected by Intellectual Property Rights law, including copyright law. Copyright and IPR is retained by the creators or other copyright holders. Terms and conditions for use of this material are defined in the End User Agreement.

\section{www.reading.ac.uk/centaur}

\section{CentAUR}

Central Archive at the University of Reading 
Reading's research outputs online 
Ralf Schneider and Sandra Dinter (eds), Transdisciplinary Perspectives on Childhood in Contemporary Britain: Literature, Media and Society, Ashgate Studies in Childhood, 1700 to the Present (New York: Routledge 2017).

\section{Children's Television and Public Service in Contemporary Britain} Jonathan Bignell

Children's television is made by adults, not by children, and the term is used to designate programmes aimed by adults at an audience of children. This chapter focuses on how the notions of the child and childhood work as discursive constructs deployed by broadcasters and regulators. Children watch not only children's television but also other kinds of television aimed at multi-generational audiences and at adults, and the chapter discusses what actual children watch in contemporary Britain. The notion of the contemporary also requires some clarification in relation to television. It only gradually became publicly available in the mid-twentieth century, and television broadcasting exemplifies modernity in its ability to address mass audiences within a domestic space (Silverstone 2006: 19-22). Like its twentieth-century precursor, radio, television is dependent on the integration of scientific innovation with large-scale industrial production; it is a product of the capitalist mass production of commodities developing from the later nineteenth century. The television set is a consumer product intended for the home, and also represents modernity in that it privatizes leisure. But while the experience of viewing has become individualized, what is broadcast is available to a collective audience and is often concerned with a shared public experience of social life. 
Television imparts information about the public world of news, sport, popular entertainment and celebrity, for example. Much of this broadcast material is live, or at least it is significant that it is recent and perceived as relevant to its audiences. In the form that television takes in Britain (and in other developed societies), television has always been contemporary and participates in the definition of what 'contemporary' means.

However, across its short history, television has changed dramatically in its technologies, modes of reception, and institutional formations (Siune and Hulten, 1998). The refinement of programme production techniques has been accompanied by improvements in image and sound definition, for example. Households own several devices capable of receiving broadcast television, as well as the ability to record, store and replay it. The number of television channels has increased dramatically, and the deregulation and globalisation of the television business has mirrored the ideologies of marketization and consumer choice that are evident in most other sectors of contemporary culture. But this chapter argues that television's identification with the contemporary, despite all the changes that have affected the medium, comes from its ability to adapt and assimilate. Like radio, television is organized and regulated at a national level, and it has inherited formats, forms and modes of address from theatre and journalism, for example. With the advent of digital communications media and the World Wide Web, television is adapting to 'convergence culture' (Jenkins 2006: 2) which is characterised by 'the flow of content across multiple media platforms, the cooperation between multiple media industries, and the migratory behaviour of media audiences'. The chapter briefly considers this historical trajectory, and also the ways that the concept of 'the child' has been figured in British television very recently. As Graeme Turner (2009: 
63) has suggested, 'rather than witnessing the end of broadcasting or the beginning of post-national television, we are simply watching these two constitutive elements renegotiate their particular roles against an unusually volatile background of hypercommercialisation and emerging technologies.' This chapter argues that the study of children's television tells us a lot about how both childhood and television are understood in culture, and how the tensions between continuity and change have affected them.

\section{Historical perspectives}

British television broadcasting began in 1936, when the British Broadcasting Corporation (BBC), which already had a monopoly on radio from 1922, was given a charter by government that gave it the exclusive right to establish a television service. In exchange for this privileged position, $\mathrm{BBC}$ was required to inform, educate and entertain the national audience (Scannell 1990). This arrangement, known as Public Service Broadcasting, meant that $\mathrm{BBC}$ made programmes in a wide range of genres (entertainment, news, current affairs, sport, original drama, religious programmes, etc.) and aimed programmes at specific audience constituencies, including children. Children's television, made by adults, included programmes supporting the school curriculum, programmes for pre-school children at home with their mothers, entertainment programmes for children and programmes for a cross-generational family audience (Oswell 1995). Television is still most often watched in the private space of the home, but in the early days of British broadcasting this was by no means the dominant way that viewers experienced the new medium. In the 1930s, public venues for watching television included railway stations, restaurants and department stores, and audiences 
watched collectively. Centralised production and dispersed individual reception of television became the norm after the Second World War, with conflicting results. First, central production and private reception matched the democratic organisation of Europe and the United States. Governments and licensed institutions could distribute information and culture universally, to promote a fairer society. Public service broadcasting attempted to raise cultural, educational and social standards. The second result was the connection with the home. Standards of living rose steadily through the twentieth century, and the home became a site for the accumulation of consumer goods and the development of new patterns of domestic leisure. Commentators were concerned about how watching television might disturb family routines and waste time compared to reading or conversation, but for most viewers watching TV was a sociable experience. Most viewing was collective, in friends' and neighbours' houses, and helped to form communities. This was especially the case in the newly built suburbs of the major cities.

Television was both attacked and defended as a medium for children. The journalist Ivor Brown (1951: 17), for instance, contributed an essay to the BBC Year Book, an annual book-length publication chronicling the corporation's activities. Defending television and rejecting claims that it was bad for children, he wrote: In my boyhood there was an advertisement headed 'Keep your Boys at Home'. No force, naturally, but a voluntary and blissful incarceration was suggested. It was to be made easy and delectable by a dining-room table which could be turned into a billiard-table. Thus was erring and straying to be checked and temptation to be killed by kindness. Television, no doubt, is doing some of the same protective work and stabilizing the Englishman's home. But on my observation, there is no 
reason to think that boys and girls, once become viewers, will never more be quitters. The sharp pleasure of banging the door on one's parents and going out to sniff the air of liberty, even if that air be only the frowst of the cinema, is surely perennial. [...] People who view do not stop going to the play or the films or the cricket-match.

The television set became an important part of the culture of the home, often positioned next to the fireplace, where families would gather in the evening and keep warm (in the age before central heating) and share entertainment experiences. Children were part this audience, addressed not only by television programmes but also an associated media and toy culture. Radio had already fulfilled a similar function, and the household, configured by and for television, was inter-generational, commercial and social. Television's address to childhood and to children was one that promoted inclusion but also individuation, shared cultural references but also taste discrimination, and various forms of stratification, distinction and inequality through which social life was reproduced.

Regular television broadcasting for children, as opposed to the occasional programmes made in the early years, began only in 1950. There was always an anxiety that the relationship between broadcaster and listener would encourage children to be passive viewers, and the response was to stress collective viewing. One long-running programme for pre-school children was Watch with Mother (1953-75) for example, while older children were expected to watch with siblings, friends or parents. Watching television physically positioned the child statically within a room, looking towards the screen, so its spatial configuration seemed to encourage physical inactivity. To counteract this, programmes for children represented children as physically and culturally active. 
The magazine programme Whirligig (1950-53), or the long-running Blue Peter (1958-), for example, featured items about children's hobbies, sport and outdoor recreation. Children were invited to interact with programmes by writing letters, taking part in charity fund-raising and volunteering, and participating in competitions. The rhetoric of address to the viewer supported this relationship, since presenters would directly address the camera, and speak to the viewer as 'you', thus positioning the child as part of the 'we' of an audience community.

The BBC monopoly on television broadcasting was broken by the introduction of commercial Independent Television (ITV) in 1955, but ITV was bound by the same legal requirement to produce Public Service programming and to inform, educate and entertain. ITV produced children's programmes in similar forms to the BBC, but with advertising breaks within and between programmes. Similarly, the introduction of BBC2 in 1964, Channel 4 in 1982 and Channel 5 in 1997 did not challenge those expectations, despite somewhat looser obligations being placed on these channels, and all five are often known collectively as Britain's main channels, traditional channels or PSB (Public Service Broadcasting) channels to reflect that continuity. The beginnings of the contemporary multi-channel environment were in the 1980s when broadcasting by satellite was introduced, but take-up was limited until 2002 when a consortium of broadcasters including BBC, ITV, Channel 4 and Sky launched Freeview. This free digital television service offered about 70 channels, including some specialising in children's television, and in 2013 analogue television was closed down.

The period since the millennium has seen significant changes in how children watch television, but also continuities that make inherited ideas about national television 
culture important. Figures published by the national media regulator, Ofcom (2014a: 4) revealed that over 98 per cent of UK children (5-15 year olds) had access to digital multichannel television in 2013, and 69 per cent of households with children had access to pay channels as well as free ones. In 2013, there were 31 children's channels of which 11 were free to view, and although programmes for children were still available on some general-audience channels the fragmentation of the child audience had several effects for broadcasters. One was that the total possible audience at any point during the day could be split up into numerous small constituencies, each watching a different channel. For channels funded by selling advertising time, a smaller audience is usually less lucrative than a larger one because channels charge advertisers according to how many thousand viewers a programme is expected to attract to the advertisements shown during it. For the $\mathrm{BBC}$, funded not by advertising but by a licence fee levied on all owners of television sets, smaller audiences could threaten the BBC's legitimacy as a provider of programmes to the whole population and thus the political will to support its funding model.

Competition for audiences and potential loss of distinctiveness among a large roster of similar channels meant that British television institutions developed strategies to address audiences in new ways. One of them was branding, and in 2002 the BBC launched its two digital channels for children: $\mathrm{CBBC}$ and $\mathrm{CBeebies,}$ respectively for sixto thirteen-year-olds and for pre-school children. Schedules were stripped into four-hour blocks, rotating three times a day, so although there was programming throughout the day it comprised many repeated programmes. BBC positioned its new channels as part of its Public Service remit. Offering a schedule that did not include any advertising was a means to appeal to parents who might be concerned about the commercialisation of 
children's television (and childhood in general). Moreover, 90 per cent of CBeebies programmes and 75 per cent of $\mathrm{CBBC}$ programmes were either British- or Europeanmade, which was a considerably greater proportion than their US-owned competitors such as the Cartoon Network or the Disney Channel. Ofcom (2014: 6) reported that 85 per cent of parents regarded Public Service Broadcasting of children's programmes as important, and over three-quarters of parents believed that $\mathrm{BBC}$ in particular was offering a range of high-quality, British-made programmes. The BBC's strategy for children's television in the digital world enabled it to identify itself as a reliable, trustworthy institution that had the best interests of children at heart. This relatively conservative, mainstream ideology demonstrated continuity with the BBC discourses from much earlier decades.

Clearly there has been change since the monopoly period when BBC was Britain's only television channel. The great majority of children (71 per cent) had access to the World Wide Web via a tablet computer in 2013 (Ofcom 2014a: 4) and over half of Britain's children reported that they like to watch video from YouTube as much or more than watching television. But Ofcom's analysis of national viewing showed that children still watch television in Britain in traditional ways. Watching television was the most common media activity for children of all ages, and children less than eight years old watched about twice as many hours of television as the hours they spent engaged with other media such as the internet or video games (Ofcom 2014a: 5). Children watched almost 17 hours of television per week each, but almost two-thirds of that time was spent watching programmes aimed an adult or family audience rather than programmes aimed specifically at children. When watching children's programmes, British programmes 
were watched 45 per cent of the time (Ofcom 2014: 10) despite the fact that only 20 per cent of children's television (in terms of programme hours) across all channels is UKmade. The largest audience of children watch in the early evening, with adults, using the household's main TV set. The most popular programmes among children (Ofcom 2014b: 226-8) were both shown in the evening and were not aimed specifically at children; they were the BBC science fiction drama Doctor Who (2005-) and the prime-time talent contest on the commercial ITV channel, Britain's Got Talent (2007-). Among younger children, the most viewed programme was BBC's screening of the Disney animated film Up (2009), but for both younger children (4-9 years old) and older ones (10-15) the BBC comedy drama for children, Gangsta Granny (2013), was among the top 20 most viewed and attracted half of the total child audience. It is not true that children no longer watch television, nor that they watch alone, nor that they largely spend their time on interactive computer devices. Continuities with the past are as significant to an understanding of television as apparent ruptures, breaks or revolutions.

\section{British television culture in a global context}

Britain has always been relatively unusual in that its television channels mainly show programmes made in Britain. Some British programmes sell overseas, either subtitled or

dubbed, and such programmes aimed at children include the BBC's rebooted Doctor Who (2005-), sold to 28 countries including Australia, Canada, France, Germany, Israel, Italy, New Zealand, Sweden, Thailand, and the SyFy channel in the USA. The animation Peppa Pig (2004-), has been screened in over 180 countries. BBC Worldwide is the commercial arm of the BBC that distributes British programmes overseas, and invests in 
programmes that it then exports. Worldwide invested $£ 14.5$ million in the pre-school programme In the Night Garden (2007-9) to build on the export success of its predecessor, Teletubbies (1997-2001), for example. Nevertheless, since the 1950s, American television has far exceeded British or any other television in export revenue and coverage, and well-known examples include Lassie (1954-73), Scooby-Doo, Where Are You? (1969) or He-Man and the Masters of the Universe (1983). Throughout the history of British television there has been strong resistance to US programmes because of the fear of Americanisation. This applies especially to children, who are considered more vulnerable to the influence of the consumerism embodied in many US toy-based series, and susceptible to the violent content in US children's programmes, especially cartoons. Across Europe, there are shared assumptions that children enjoy puppetry and animation, that they identify with anthropomorphised animals and child-like characters, and that they enjoy songs and music. A fundamental conception of childhood, originating in the late $18^{\text {th }}$ century, links the great majority of programme producers, television programme buyers and executives, and the parents, politicians and commentators who have shaped children's television in Europe. Children's programmes can only be so successfully international because of the existence of transnational institutions and technologies for sharing television programming, and a shared sense of what childhood is. Britain has played a leading role in making domestic programmes for children that can be assimilated into the commercial networks of television trading.

One specific example is the television series If You Were Me (1971) screened sporadically on the main BBC1 channel. It was scheduled at $5.15 \mathrm{pm}$, when most children would have recently returned home after school. In total there were 22 half-hour 
episodes, shown in 1971, 1972 and 1975. The premise was summed up in the strapline printed in the BBC's listings magazine, Radio Times (1971: 36): 'You stay in my house I'll stay in your house. You sleep in my bed I'll sleep in your bed. You come to my school I'll come to your school ...'. Thirteen-year-old boys and girls from different countries swapped lives, and were filmed at home and at school. The programme was a co-production, and comprised films made for television by European broadcasters who belonged to the European Broadcasting Union, including AVRO (Netherlands), Bayerischer Rundfunk (southern Germany), the BBC in Britain, CBC (Canada), RTB (Yugoslavia), RTT (Tunisia), PBS (USA), RAI (Italy) and TRT (Turkey). The films were circulated to the fellow members for showing in their own national territory, and were given translated voice-over soundtracks in each national language. The producer was Molly Cox, who worked on the BBC story-reading series Jackanory in 1965-66, and later on Why Don't You Switch Off Your Television Set and Go and Do Something Less Boring Instead (1973) which featured film segments authored by children themselves. The director was Tim Byford, who worked on the staff of BBC's Children's Department, directing film segments about children's lives for the magazine programme Blue Peter. In common with many British programmes, short runs of episodes were made, beginning with six films shown in 1971. In the first episode, James Currie from Melton Mowbray in Leicestershire swapped lives with Andrea Franchi from Assisi in Italy. In the following week, Nicola French from the village of Swanmore in Hampshire exchanged with Milica Zaric from a Serbian village in Yugoslavia. In the third episode, Keith Powell from Rawmarsh in Yorkshire swapped with Kamel Khalfallah from Dar Cha Bane in Tunisia, and on 24 February 1971, Campbell Aiken from Aberdeen in 
Scotland exchanged lives with Jan Oosterbroek from Hoorn in Holland. In the episode from 3 March 1971, Jane Curtis from the village of Lavenham in Suffolk swapped with Stephanie Kranz from a Bavarian village in Germany. In the final episode of the first series, on 10 March 1971, Nicola Snook from Bath exchanged with Ginger Gonzales from Salt Lake City, Utah, in the USA. The intention was to show the diversity of children's lives, and also the potential equivalences between them. So, for example, there were featured children who came from villages and swapped lives with village children from another country. In the same way, children from major cities swapped with other urban children, and the ages of the children were similar in each case (not least because they were integrated into the school systems of each country). There was an important limitation on the recognition of the overseas childhoods being represented. Since in each programme it was a British child who travelled, and with whom the overseas child swapped, the overseas child could only be seen in relation to a known UK childhood that stays the same as the measure of comparison. If You Were Me was conceptually linked to the concept of Town Twinning, on which school exchange schemes and pen-friend relationships between children were often built. Twinning had been set up in 1947 after the Second World War to foster friendship and understanding between former enemies, and to encourage trade and tourism. It was a high-profile means to create European identity by acknowledging and repudiating national conflicts, featuring twinning between cities devastated by war like Coventry (UK), Dresden (Germany) and Stalingrad (USSR), for example. Children's mobility and communication between countries was a concrete instance of this transnational idealism. 
Within Britain, comparison programmes featuring children were not new, with the most celebrated example being the documentary series 7 Up made by the commercial broadcaster Granada TV in 1964, initially for its current affairs series World in Action. Annual editions of the $U p$ series followed the life stories of the same children, chosen from different social classes and geographical locations around the UK. But it was designed for viewing by adults as an analytical study of cultural difference and class privilege, and was longitudinal - it is still being made some 50 years later. The EBU's infrastructure made If You Were Me possible. The EBU was formed in 1950 by 23 broadcasters across Europe and the Mediterranean, with further national members and associate members (some of them outside Europe, such as broadcasters from Canada, Japan, Mexico, Brazil, India and the USA) subsequently joining from the public and commercial sectors. The EBU's unstated ideology was that childhood was interesting to its multinational audience, and comprehensible to them as a shared concept or currency that was exchangeable across borders. Like money, it was nationally distinctive but the childhood of one country could be compared with that of another. In 1971, the year that If You Were Me began, the Eurovision network broadcast Children of the World, hosted by US actor Danny Kaye, which presented segments representing children's lives in 45 countries, using 22 land stations and two satellites. The idea of uniting the world's audiences by means of transnational live broadcasting was not new, and was celebrated by, for example, the programme Our World (1967) in which The Beatles performed 'All You Need is Love'. The ideal was inclusiveness despite diversity, and broadcasting would enable people to recognize their distinctiveness but also their common membership in a 'family of man'. The ideologies associated with childhood made it 
appear to be a common ground on which such a broadcast event could be based. As I have previously suggested (Bignell 2011: 181): 'The circulation of children's television across borders has drawn on transnational conceptions of what childhood is and what child audiences want and need. That circulation has not been prevented by national regulatory regimes or political boundaries like the Iron Curtain ... [and] the child audience has been constructed as a transnational entity that could be addressed and provided for by transnational programming.'

\section{Effects and regulation}

Adults consistently try to protect children from television, on the basis of defining childhood by its inherent value but also its transience and vulnerability. In the developed nations of the Western world, childhood is seen in two contrasting and contradictory ways. On one hand, children are also regarded as innocent, and naturally predisposed to be good. But on the other hand, children have been regarded as irrational, immoral and in need of adult guidance, and this has justified regulation and censorship. Children watching television have been a focus of studies looking for evidence of (usually negative) effects for several decades (Lemish 2007: 69-100). In the 1950s and 1960s, researchers devised interview techniques or opportunities for play in which children could be monitored, to see whether the television they had viewed made them behave differently. Results were inconclusive, but this work legitimated campaigns for the regulation of children's television. The aim was to protect what were seen as vulnerable audiences from programmes that might turn children into anti-social adults. Binary oppositions between rational child and irrational child, active and passive, agent and 
victim have underlain much of the debate on both childhood and popular culture for more than a century. Parents, educators and regulators in both the UK and USA have argued that programmes for children should have regard for the functions of television in education and child development. These responsibilities on the part of programmemakers and broadcasters have underpinned much of the discourse of British television production in the public service tradition. For example, the British BBC producer Roger Singleton-Turner (1994: 23) argues that the competencies and knowledge held by children and the adults who make children's television are different, and he claims that: The whole grammar of television needs to be learnt by each viewer. There is evidence that the language of film and television is learnt in a similar way to spoken language and that children of increasing maturity accept with understanding an increasing vocabulary of filmic conventions.

Therefore, narrative forms should be relatively linear and clear, to avoid the child creating 'extraordinary constructions in his [sic] mind to explain what he has seen'. A discursive model of child development is constructed as an evolutionary learning process which moves teleologically towards the normative adult viewer. The use of this developmental schema prescribes the audio-visual form of programmes, according to the 'stage' in development which the child is assumed to be at, with the simplest forms for the youngest audience. Relations between long shots and close ups should be signposted (to avoid confusion over the sizes of objects and people), time ellipses between shots should be rare in programmes for young children, and cutting rates should be slower than for an adult audience. In essence, the form of children's programmes comes to resemble early cinema, and repeats the 'evolution' of film from the static camera shooting 
theatrical boxed sets, with little cutting or change of frame size, to a contemporary style of rapid montage, fast cutting, and 'unmotivated' use of pan or close up in programmes for older children.

David Buckingham (1996) cuts through this, adducing children's and parents' talk about television to focus on the 'positive' and 'negative' emotional responses to television. Buckingham discovers that both watching television and talking about television are important means for children to understand themselves and others, and also to perform their own identities to themselves and others. This dynamic interaction involves gaining and deploying knowledge of television codes and conventions, such as distinctions between genres, narrative forms, and contextualisation of the programme text through knowledge about the production processes which gave rise to it. Children sometimes seek out disturbing programmes in order to test their own maturity at coping with troubling emotions. It is not simply pleasure that drives viewing preferences, but also a desire to self-educate and confront challenging material. Television programmes can empower their audience by requiring attention to the conventions of signification in the television medium. So a positive outcome of effects research, however misguided it may be, has been the teaching of 'media literacy' (also known simply as 'media education') in British schools, on the assumption that if children understood how television representations were constructed they would be better able to negotiate the meanings of television for themselves. Long ago a major report for the government by Lord Newsom and the Central Advisory Council for Education (Newsom 1963: 155), which analysed the British state-funded school system and its curricula, explicitly called for 'the study of film and television in their own right, as powerful forces in our culture 
and significant sources of language and ideas.' Media literacy empowers child viewers to recognize the degree of modality (the closeness or distance of the fit between reality and representation) in the material they see on screen (Hodge and Tripp 1986: 100-131). Work on cognitive and emotional responses to television argues that watching and talking about television play a significant role in children's self-understanding in relation to others and to society. Arguments for media literacy accept that adult control over children's viewing can only ever be partial, so the wish to protect them is displaced into a wish to equip them with skills for self-defence. Watching television is pleasurable for children, but it is also an essential part of their integration into society as a whole.

The recognition that television and other mass communications media have shaped how childhood is experienced and thought about has led to pronouncements such Neil Postman's (1983) that television puts an end to childhood. Children are addressed similarly to adults, especially as consumers, Postman argued, and adults are offered opportunities for recreation and play in similar ways to children. While this thesis was presented as a critique that argued for the preservation and protection of childhood, a related diagnosis of the importance of media culture by Buckingham (2000) views contemporary media culture as a vigorous arena for the realisation of child identities. Contemporary television and the associated media of computer games, films and toys offer a plethora of images and experiences that shape different, possible modes of childhood. For Buckingham, contemporary childhood is a performance, in which the identity of the child is repeatedly staged for audiences such as siblings, friends, and adults including parents and teachers. Television is thus an important resource for the making of childhood identity. 
Childhood only makes sense in distinction to adulthood, and it is adults who are responsible for broadcasting regulations and who make decisions about what children should or should not see on television. Broadcasting in Britain is largely self-regulated, on the basis of codes and guidelines drawn up and interpreted by the Office of Communications (Ofcom), a body appointed by the government to 'further the interests of citizens in communication matters' and to 'further the interests of consumers', which are of course potentially conflicting aims. The main channels have for a long time agreed on a 9.00 p.m. 'watershed', before which time programmes that could be offensive or disturbing to children will not be broadcast. Uncut films with a 15 age rating cannot be shown before 8.00 p.m. even on a dedicated film channel, and films with an 18 rating cannot be shown before 9.00 p.m. on any channel. Potential or actual upset to children is often cited as a ground for viewer complaints; for example, there was a controversy in 2010 when the pop stars Rhianna and Christina Aguilera performed sexualised dance routines during the final programme of The X Factor talent show. The X Factor is on the main channel ITV1, shown in the early evening, and is watched by both adults and children (often viewing together in the same room), and this familial, domestic context made protests by adults on behalf of children likely. But Ofcom has less control over minority digital channels, where sexual content is much stronger, than it has over the dominant mass audience channels like ITV1. For example, Ofcom (2010) published the results of a formal investigation that found that the companies Bang Channels and Bang Media had breached the Broadcasting Code with their programmes Early Bird and The Pad in November 2010. In these programmes, broadcast in the early morning on a channel called Tease Me, young scantily-clad women stroked themselves, adopted sexual 
body-positions, and jiggled their breasts, among other things. The aim was to invite viewers to phone premium-rate chat lines, whose numbers were advertised via on-screen captions. Ofcom decided that the Tease Me programmes had caused offence and could be seen by children because of the time of day when they were broadcast.

In 2007 the regulator decided (Ofcom 2007) that advertising 'junk food' during children's television programming might encourage children to consume too much fat, sugar and salt, following an investigation and consultation with interested groups. Ofcom calculated that banning these ads would reduce child obesity and save about $£ 1$ billion on medical treatment for overweight children. But the effect was that Britain's main commercial channel, ITV, withdrew from commissioning new children's programmes since the advertising ban meant it could not gain revenue from the companies that bought advertising time during children's programmes on the channel. ITV had previously spent about $£ 30$ million each year on new British children’s programmes (Brown 2010), but instead commissioned factual entertainment and comedy for adults that would occupy the schedule slots vacated by children's television. Although programmes for children have been part of the British television landscape since the beginning of the medium, commercial pressures, competition between the large numbers of channels now available, and wider political concerns about public health came together to threaten the genre.

Ofcom had to compromise between the widely-supported idea that children's programmes are beneficial, versus the economics of deregulated multi-channel television.

\section{Audiences as children}


Protecting children from television is connected to assumptions about how other vulnerable groups can be adversely affected by television. Elites tend to consider mass audiences as 'them' in contrast to the more sophisticated 'us', and mass audiences have been regarded as childlike and unable to discriminate between programmes. In the 1960s, a liberal discourse on contemporary media gained currency by linking aims to expand audiences' intellectual horizons with a discourse that claimed childlike openness to experiment, and the valuation of childhood as a mode of experience that liberated perception from the dry conventionality of 'adult' relationships with contemporary media. Marshall McLuhan (1987, first published 1964), for example, argued that media users, especially television viewers, interacted with media in a way parallel to children's supposed creative and involved relation to the world around them. McLuhan's work proposed that electronic media like television surpassed the linear, rationalistic and literary heritage of Western civilisation by returning to an iconic, tribal and bardic mode which he associated both with 'primitive' tribal societies and with Modernist works of art. Young people, McLuhan argued, were better equipped than adults to respond to television and other recent media forms, as well as having the energy to bring about social change. Like some of the popular movements of the 1960s which drew on Romantic conceptions of nature, childhood and organic social utopianism, this use of the figure of the child represents a call for the reinvigoration of technological culture by a paradoxical return to a preexisting Nature (Heywood et al, 2017). Both broadly positive and negative theories of media draw on childhood in ways which largely reinforce conventional understandings of the child as different to adults, and socially and culturally incomplete. For both pessimists and optimists, the figure of the child is a key component 
in understanding a Western metropolitan society perceived to be dominated in new and significant ways by mass media culture.

The media theorist John Hartley argues that broadcasters think about audiences in a way that is parallel to adults' attitudes to children. Hartley (1992: 17, emphasis in the original) argues that 'there's a struggle between what are presumed to be paedocratic audience practices on the one hand (governed by childlike qualities), and pedagogic discourses on the other (government over childish tendencies)'. Although television viewers can be addressed in a range of ways, for example as citizens, as workers, or as members of ethnic, gender or class groups, Hartley argues that television is understood primarily as an entertainment medium, and focuses on the delivery of pleasure to its audience. Despite the fact that there are some genres, such as news, that address the audience with information, and genres such as some children's television programmes that aim to educate the audience, the majority of programmes are either entertainment or use entertainment forms in order to attract viewers, retain them on a channel, and encourage viewing of future programmes. Hartley claims that broadcasters 'appeal to the playful, imaginative, fantasy, irresponsible aspects of adult behaviour. They seek the common personal ground that unites diverse and often directly antagonistic groupings in a given population. What better, then, than a fictional version of everyone's supposed childlike tendencies which might be understood as predating such social groupings?' The argument is that treating the audience as children is a strategy of control.

The other strand of Hartley's argument is that television also aims to instruct television viewers, just as adults seek to instruct and train children. Some programmes have an explicit educational aim, but also the promotion of television programmes, 
trailers and reviews of programmes instruct the audience about what is available for them to watch, and how they might choose to watch it. The regulation of television both within the industry and by official regulatory bodies can also be regarded as instructional. Institutions control and instruct the audience in the way that adults seek to control the behaviour of children. By discussing the television audience in this way, Hartley draws our attention to the contradictory status of the audience in television culture. On one hand, the audience is very valuable to broadcasters. It is the group that they address, and the source of their income. Like the love that adults have for their children, broadcasters show care and interest in the audience. On the other hand, audiences can be hard to understand, difficult to communicate with, and it is difficult for broadcasters and regulators to gain control of viewers' attitudes and behaviour. Like children, audiences can be unruly and undisciplined. Broadcasters, regulators, commentators and parents draw on their anxiety about what children might see on television in order to frame ideological strategies that unconsciously depend on assumptions about the audience as a whole, both adults and children.

The original meaning of 'broadcasting' was the scattering of seed over the soil, a metaphor that has become the accepted term for the transmission of radio and television signals (Winston 1998: 77). Thus broadcasting as dissemination retains the connotations of fertility, growth, renewal and promise that it inherits from that agricultural language. At the same time, both broadcasting and dissemination also signify the control of the process by a single agent, the indiscriminate nature of the distributive act, the necessary delay between casting the seed (or sending the signal) and its arrival at its destination, and the impossibility of knowing whether the seed or message will take hold and lead to a 
desired result. Like the concept of childhood, broadcasting as a concept holds together contrasting and mutually implicated notions, implying fertility but also uncertainty. What is at stake here is whether communicative address and interaction can establish a substantial relation between two figures, or whether it is evidence of an absence of relation. It is this question that Jacqueline Rose (1984: 1) elaborated in her landmark study of literature for children, in which she concluded: 'Children's literature is impossible, not in the sense that it cannot be written (that would be nonsense), but that it hangs on an impossibility of which it rarely ventures to speak. This is the impossible relation between adult and child'. This chapter argues a similar position about broadcasting for children. Non-communication, as much as communication, is inherent in the nature of broadcasting itself, where messages may not arrive, may not be understood, or may fail to produce a desired effect. Contemporary interactive forms of children's media might promise greater benefit to children, and fewer attempts to exercise power over their viewership, but they also imply greater investment in the communicative relation. Inasmuch as 'the child' is necessarily an 'other', he or she is always elsewhere.

\section{Bibliography}

BBC (1971), Radio Times. London edition. 30 January - 5 February.

Bignell, J. (2011). 'Television for Children: Problems of National Specificity and Globalisation.' In: K. Lesnik-Oberstein (ed.), Children in Culture, Revisited: Further Approaches to Childhood. Basingstoke: Palgrave. Pp. 167-185.

Bignell, J., and A. Fickers (eds) (2008). A European Television History. New York: Wiley-Blackwell. 
Brown, I. (1951). 'T.V. in the Englishman's Castle.' In: BBC Year Book 1951. London: BBC. Pp. 17-19.

Brown, M. (2010). 'Is funding for kid's TV just a fantasy?', The Guardian, Media section, 14 June. P. 6.

Buckingham, D. (2000). After the Death of Childhood: Growing Up in the Age of Electronic Media. Cambridge: Polity.

Buckingham, D. (1996). Moving Images: Understanding Children's Emotional

Responses to Television. Manchester: Manchester University Press.

Hartley, J. (1992). Tele-ology: Studies in Television. London: Routledge.

Hartley, I. (1983). Goodnight Children ... Everywhere. Scarborough: Midas.

Heyood, S. et al (2017). The Children's '68. https://children68.hypotheses.org

Hodge, B. and D. Tripp (1986). Children and Television: A Semiotic Approach.

Cambridge: Polity.

Jenkins, H. (2006). Convergence Culture. Where Old and New Media Collide. New

York: New York University Press.

Lemish, D. (2007). Children and Television: A Global Perspective. Oxford: Blackwell.

Lesnik-Oberstein, K. (1996). 'Defining Children’s Literature and Childhood.' In: P. Hunt (ed). International Companion Encyclopedia of Children's Literature. London:

Routledge. Pp. 15-29.

McLuhan, M. (1987). Understanding Media: The Extensions of Man. London: Ark.

Newsom, J. (1963). Half Our Future: A Report of the Central Advisory Council for

Education. London: HMSO. 
Ofcom (2007). Television Advertising of Food and Drink Products to Children, 22

February. https://www.ofcom.org.uk/consultations-and-statements/category-

2/foodads_new/statement

Ofcom (2010). Breach Finding: Bang Channels Ltd., 26 November.

https://www.ofcom.org.uk/_data/assets/pdf_file/0023/72176/breach.pdf

Ofcom (2014a). Public Service Broadcasting Report, 2014: Children's PSB Summary.

London: Ofcom.

Ofcom (2014b). Children and Parents: Media Use and Attitudes Report. London: Ofcom.

Oswell, D. (1995). 'Watching with Mother in the Early 1950s.' In: C. Bazalgette and D.

Buckingham (eds). In Front of the Children: Screen Entertainment and Young Audiences.

London: British Film Institute. Pp. 34-46.

Postman, N. (1983). The Disappearance of Childhood. New York: Vintage.

Rose, J. (1984). The Case of Peter Pan, or, the Impossibility of Children's Fiction.

London: Macmillan.

Scannell, P. (1990). 'Public Service Broadcasting: The History of a Concept.' In:

Goodwin, A. and Whannel, G. (eds). Understanding Television. London: Routledge.

Pp.11-29.

Silverstone, R. (2006). Television and Everyday Life. London: Routledge.

Singleton-Turner, R. (1994). Television and Children. London: BBC.

Siune, K., and Hulten, O. (1998). 'Does Public Broadcasting have a Future?' In: D.

McQuail and K. Siune (eds.) Media Policy: Convergence, Concentration, Commerce.

London: Sage. Pp. 23-37. 
Turner, G. (2009). 'Television and Nation: Does this Matter Any More?’ In: G. Turner \& J. Tay (eds), Television After TV. London: Routledge. Pp. 54-64.

Winston, B. (1998). Media Technology and Society, A History: From the Telegraph to the Internet. London: Routledge. 